\title{
Why Do Voters Change Their Mind during an Election Campaign? An Analysis of the Determinants of Campaign Volatility at the 2014 Belgian Federal Elections
}

\author{
Simon Willocq \\ CEVIPOL, Université libre de Bruxelles, Brussels, Belgium \\ Email: swillocq@ulb.ac.be
}

How to cite this paper: Willocq, S. (2016). Why Do Voters Change Their Mind during an Election Campaign? An Analysis of the Determinants of Campaign Volatility at the 2014 Belgian Federal Elections. Open Journal of Political Science, 6, 363-386. http://dx.doi.org/10.4236/ojps.2016.64033

Received: August 5, 2016

Accepted: September 16, 2016

Published: September 19, 2016

Copyright $\odot 2016$ by author and Scientific Research Publishing Inc. This work is licensed under the Creative Commons Attribution International License (CC BY 4.0).

http://creativecommons.org/licenses/by/4.0/ (c) (i) Open Access

\begin{abstract}
This article examines the causes of stability and change in vote intentions during the 2014 Belgian federal election campaign. Drawing on data from the 2014 Parti Rep Belgian Voter Survey, our study aims to explain why a large number of voters have switched their vote intention in the weeks preceding the federal elections. To this end, we test a series of hypotheses drawn from different theories often referred to in the literature to account for campaign volatility. The results of our analysis reveal that voters can decide to change their vote preferences during the campaign due to strategic considerations related to their perceptions of the coalition potentials of parties. We also find that voters with a low level of political interest are more likely than highly interested voters to switch from one party to another in the weeks preceding the electoral contest. Unsurprisingly, a high degree of affection for the favourite party proves to be a barrier against campaign volatility. The higher the level of affect directed to the most preferred party, the more stable will be the vote intention. Moreover, results show that citizens with a low level of external political efficacy are more prone than others to switch parties in the last weeks of the campaign. By contrast, the ideological profile of the voter has no significant impact on campaign volatility.
\end{abstract}

\section{Keywords}

Election Campaign Volatility, Strategic Voting, Political Sophistication,

Political Disaffection, Ideological Profile

\section{Introduction}

Since the 1970s, strong empirical evidence has accumulated demonstrating that voting 
behaviour is changing in Western Europe. While the 1950s and 1960s had been characterised by a high degree of electoral stability in most European democracies, the last four decades have been marked by an increasing electoral volatility (Crewe \& Denver, 1985; Dalton, McAllister, \& Wattenberg, 2000; Drummond, 2006; Mair, 2005; Pedersen, 1979). One nowadays observes larger changes in vote shares between two consecutive electoral contests, which makes elections results much more unpredictable than in the past. This rising level of variability in elections outcomes seems to contradict Lipset and Rokkan's hypothesis of a freezing of European party systems (Lipset \& Rokkan, 1967). In line with the indications provided by aggregate elections statistics, individual-level survey data unambiguously show that European voters tend to switch parties between successive elections more often than they did some decades ago (Dalton et al., 2000).

Besides leading to this increase in inter-election volatility, the growing instability of voters' party preferences also translates into a rise in campaign volatility. Indeed, a larger proportion of voters change their vote intention and switch from one party to another during the months preceding the elections (Dalton et al., 2000; Granberg \& Holmberg, 1990, 1991; Lachat, 2007). These campaign switchers undoubtedly deserve specific attention, since they often play a crucial role in determining the final outcomes of the election. From a theoretical standpoint, the phenomenon of campaign volatility offers a challenge to classic models of voting behaviour which emphasize the image of a stable and loyal voter whose party choice is made even before the start of the campaign and is largely determined by "long-term" factors such as sociodemographic characteristics (Lazarsfeld, Berelson, \& Gaudet, 1968) or partisan allegiances (Campbell, Converse, Miller, \& Stokes, 1960). Faced with this challenge, several scholars have examined the causes of campaign volatility and brought some interesting insights into why some voters shift their vote intention during the weeks preceding the electoral contest

(Dassonneville, 2012; Granberg \& Holmber, 1990, 1991; Lachat, 2007; Van Der Meer, Van Elsas, Lubbe, \& Van der Brug, 2015; Walgrave, Lefevere, \& Hooghe, 2010). Yet, their studies often focus on one or two specific type(s) of explanation and thus lack an encompassing perspective.

The present article precisely aims to provide a more comprehensive understanding of campaign volatility. To this end, we seek to identify the main determinants of stability and change in vote intentions during the 2014 Belgian federal election campaign. Using panel data from the 2014 PartiRep Belgian Voter Survey, we test four hypotheses that have been suggested in previous research to explain electoral volatility in general and campaign volatility in particular. The first one holds that strategic considerations can lead voters to change their vote preferences during the campaign. The second hypothesis, which is drawn from the traditional floating voter theory (Berelson, Lazarsfeld, \& McPhee, 1963), argues that voters with a low level of political sophistication are more likely than highly sophisticated voters to change their mind in the weeks preceding the electoral contest. The third hypothesis, which is drawn from the frustrated floating voter theory developed by Zelle (1995), assumes that campaign volatility can be largely attributed to political dissatisfaction. The last hypothesis suggests that voters with a 
moderate ideological profile are more volatile than those with radical ideological orientations. Far from being mutually exclusive, these four types of explanations for campaign switching seem to be quite complementary.

The 2014 Belgian federal elections provide an ideal setting for studying the phenomenon of campaign volatility. As it has been shown in previous work (Dassonneville, 2012; Walgrave et al., 2010), Belgian voters usually display a high level of uncertainty in their party preferences in the weeks preceding the elections and the proportion of campaign switchers often proves to be relatively high especially when compared to figures observed in other Western democracies. The 2014 PartiRep survey questionnaire contains a question on timing of the vote decision, which can be seen as a subjective measure of the level of voters' uncertainty during the federal election campaign. Only $44 \%$ of the respondents report having made their voting choice before the start of the campaign, whereas 56\% report having delayed their electoral decision until the campaign was under way. These figures seem to indicate that a large majority of the Belgian voters had not yet taken their final vote decision when the campaign began and that they could still consider the possibility to change their voting preferences in the last weeks before Election Day.

This article is divided into four sections. The first part reviews different theories that are often referred to in the literature to account for campaign volatility. The second section presents the data and describes the operationalization of the dependent and independent variables. The third part is dedicated to the empirical testing of our hypotheses and deals with the results of our bivariate and multivariate analyses. The final section contains some concluding remarks on the implications of our findings as well as some suggestions for further research.

\section{Theoretical Framework}

In this section, we consider four different types of potential explanations for electoral volatility in general and for campaign volatility in particular ${ }^{1}$. Strategic voting is a first factor that is thought to induce instability in voters' party preferences (Bartolini \& Mair, 1990; Bischoff, 2013; McGregor, 2012). Before dealing with the relationship between tactical voting and electoral volatility, it is necessary to define the concept of strategic voting. Students of electoral behaviour usually distinguish two types of individuals: sincere voters and strategic voters. Sincere voters are those individuals who simply cast a ballot for their most preferred party regardless of the consequences of their choice on election outcomes, seat allocation and government formation. Strategic or tactical voters, on the other hand, are those citizens who cast a vote for a less preferred party option, in order to influence the outcome of an election or the government formation (Blais, Nadeau, Gidengil, \& Nevitte, 2001). In fact, the main goal of these

${ }^{1}$ In this section, we review not only specific studies on campaign switching, but also the rich literature on inter-election switching. Although there is, at first glance, no logical connexion between the two types of volatility, some scholars have noticed that the mechanisms accounting for campaign switching did not differ fundamentally from the mechanisms underlying inter-election switching (e.g. Dassonneville, 2012; Lachat, 2007; Van Der Meer et al., 2015). Hence, the good predictors of inter-election volatility, which have been identified in previous work, can be regarded as potential predictors of campaign volatility. 
voters is to prevent a party that they dislike from winning the elections. Being aware of the relative competitive position of each party, strategic voters acknowledge that their favourite party has little (or no) chance of success. Since they want to avoid wasting their votes, they refrain to vote for that party and decide to cast a ballot for a less preferred party that seems to be the most capable of defeating their least preferred party option (Blais et al., 2001; McGregor, 2012). There are two main types of tactical voting: seat-maximizing and government-maximizing voting (Cox, 1997). The willingness to maximize seats means that the voter cares about the consequences of his/her voting choice on seat allocation. In this perspective, a vote is wasted when it is cast for a party that seems to have no chance of garnering the vote share necessary to win seats. The other type of strategic voting, namely government-maximizing voting, means that the voter wants to choose a party that can play a role in the process of government formation. In other words, he/she wants to avoid wasting his/her vote on a party that is not capable of influencing the coalition formation, even if it can win seats (Cox, 1997).

In their seminal study on electoral change in Western Europe between 1885 and 1985, Bartolini and Mair (1990) hypothesize that institutional incentives for tactical voting lead to higher levels of inter-election volatility. They suggest a causal mechanism linked to changes in the viability of parties, which can occur between two consecutive elections. A party does experience a change in viability when its ability (real or perceived) to win seats or to affect the process of government formation changes between two successive elections (Bartolini \& Mair, 1990). The explanation for why strategic incentives can stimulate vote switching is straightforward. In systems that provide no incentive for strategic voting, electors can switch from one party to another for substantive reasons, namely shifts in their own political opinions or changes in parties' policies or platforms from one election to the next. In countries where the electoral system provides strategic incentives, voters can switch parties not only for these substantive reasons, but also for tactical reasons related to changes in the viability of parties between two successive elections. Thus, there are good reasons to expect the level of volatility to be higher in systems that provide strategic incentives. According to Bartolini and Mair, rational voters who factor tactical considerations into their vote decision should be more likely than sincere voters to change parties from one election to the next. For instance, if a strategic voter thinks that the party he/she voted for in the previous elections has become less capable of winning seats or influencing government formation, he/she will probably decide to abandon that party and choose a more viable party option. In contrast, if a sincere voter believes that the party he/she previously endorsed has become less competitive, he/she will probably remain loyal to that party regardless of the efficacy of his/her vote in terms of seat allocation or coalition formation. Admittedly, Bartolini and Mair's argument appears to be quite convincing from a theoretical standpoint, but it must be pointed out that the results of their analysis did not provide empirical evidence in support of their hypothesis.

In her comparative study on the determinants of inter-election volatility in 22 countries, Bischoff (2013) further examined the relationship between strategic voting and 
party switching. Choosing another type of operationalization than that offered by Bartolini and Mair, she managed to demonstrate that tactical voting did induce instability in voters' partisan choices. While Bartolini and Mair' study as well as Bischoff study were based on aggregate-level data and analysed the impact of strategic voting on inter-election volatility, McGregor (2012) made use of individual-level data from the Canadian Elections Studies in order to investigate the link between tactical voting and campaign volatility. He found strategic voters to be much more likely than sincere voters to change their vote preferences during the campaign (McGregor, 2012).

Despite the three above mentioned studies, the relationship between tactical voting and electoral volatility remains an understudied topic. There has so far been very few works done on the question whether voters' perceptions about the viability of parties in terms of influencing the government formation may affect the stability of vote preferences. The present article precisely aims to determine whether citizens' evaluations of the coalition potentials of parties ${ }^{2}$ have an effect on the stability of their vote intentions in the weeks preceding an election. We hypothesize that the probability of campaign volatility can be strongly influenced by the way in which the voter evaluates the coalition potential of the party he/she intends to vote for at the launch of the campaign. According to our hypothesis, if a voter considers that the party he/she plans to vote for at the start of the campaign has a good chance of joining the government, he/she should stick to his/her vote intention and cast a ballot for that party on Election Day. Conversely, if a voter thinks that the party he/she intends to vote for at the beginning of the campaign has little or no chance of gaining office, he/she should be more likely to change his/her mind during the campaign period and to shift to a more viable party option.

Hypothesis 1: The higher the perceived coalition potential of the party the respondent planned to vote for at the start of the campaign, the more stable will be the vote intention.

The level of political sophistication is a second factor that may contribute to the explanation of stability and change in vote intentions. Although over the last half century, scholars have widely investigated the influence of political sophistication on electoral volatility, their opinions still differ on the question whether a high level of political expertise increases or decreases instability of voters' party preferences. In their pioneer work, the researchers of the Columbia school put forward the floating voter theory which holds that electoral volatility is higher among voters with a low level of political sophistication (Berelson et al., 1963; Lazarsfeld et al., 1968). The results of their studies conducted in the 1940s and 1950s indicated that uninformed and uninterested citizens were more inclined than highly sophisticated voters to switch from one party to another both between two consecutive elections and during the campaign. On the basis of these findings, Lazarsfeld and his colleagues sketched the negative image of an apathetic floating voter whose unstable electoral behaviour could be attributed to his/her lack of

${ }^{2}$ As explained earlier, two types of tactical voting can be distinguished: seat-maximizing and governmentmaximizing voting. In our analysis, we will not examine seat-maximizing voting. We will focus on government-maximizing voting and its effect on campaign volatility. 
political interest and his/her indifference about the electoral process.

Since the 1980s however, the traditional floating voter hypothesis has been challenged, with several scholars pointing at the emergence of a new floating voter (Dalton, 2013; Dalton et al., 2000; Habert \& Lancelot, 1988). The cognitive mobilization theory developed by Dalton suggests that uncertainty and instability in voting behaviour are the highest among highly sophisticated voters. According to this theory, the appearance of a sophisticated floating voter can be seen as a consequence of the process of cognitive mobilization. That process encompasses two distinct aspects: on the one hand, the spread of education which increases citizens' cognitive skills, and on the other hand, the development of mass media which decreases the cost of acquiring political information (Dalton, 1984; see also Inglehart, 1977). According to Dalton and his colleagues (2000), these two evolutions have led to the emergence of a growing group of sophisticated voters who possess the necessary skills and resources to manage the complexity of politics and who are able to make their own independent electoral choices. While less sophisticated voters would tend to rely on their "long-term" partisan loyalties to guide their voting decisions, cognitively mobilized voters would not have to use these partisan cues and would be more susceptible to "short-term" forces such as issues, candidates and past performances when choosing what party to vote for. Since "short-term" factors are, by definition, much more dynamic and much more erratic than partisan allegiances, voters with a high level of political sophistication should be more uncertain and more unstable in their voting preferences than less sophisticated voters (Dalton, 1984, 2007, 2013; Dalton et al., 2000; Habert \& Lancelot, 1988). Some studies have provided empirical evidence in support of the cognitive mobilization theory, by showing that better educated and well-informed citizens were more volatile than voters with a low level of political expertise (Dalton, 2007, 2013; Habert \& Lancelot, 1988). While the traditional floating voter theory of the Columbia school describes an apathetic floating voter, the cognitive mobilization theory puts forward a rational voter making his/her electoral choices on the basis of issues and past performances, who comes close to the image of the ideal citizen depicted in classic theories of democracy.

Even though the cognitive mobilization hypothesis has received some empirical support in the above mentioned literature, its validity is questioned by recent work. Indeed, a large number of studies conducted in the last two decades clearly demonstrate that political sophistication does not contribute to volatility, but to stability. Less educated and poorly informed citizens are often found to be more prone than sophisticated voters to switch parties between two successive elections and to alter their vote intention during a campaign (Albright, 2009; Boy \& Dupoirier, 1990; Jaffre \& Chiche, 1997; Marthaler, 2008; Muxel, 2009; Tiberj, 2015; Walgrave et al., 2010). These recent findings largely concord with the traditional floating voter hypothesis (Berelson et al., 1963; Lazarsfeld et al., 1968).

In this rich debate on the effect of political sophistication on electoral volatility, there is a third theoretical perspective developed by Converse (1962), which rejects both the traditional floating voter hypothesis and the cognitive mobilization hypothesis. Indeed, 
this third perspective assumes that political expertise neither has a stabilizing impact on voting choices, nor stimulates voter's volatility. It rather suggests that the relationship between political sophistication and electoral volatility is curvilinear. Some scholars have empirically established the existence of such a relationship, with the predicted probability of party switching being the highest among voters with a moderate level of political expertise (Converse, 1962; Dassonneville \& Dejaeghere, 2014; Kuhn, 2009; Lachat, 2007; Van Der Meer et al., 2015). As there are many contradictory results in the literature, we may not have clear expectations about what effect political expertise may have on volatility (leading to stability, stimulating volatility or a curvilinear effect?). In the present article, we test the original floating voter hypothesis confirmed by recent research and thus expect political sophistication to have a stabilizing impact on voters' party preferences.

Hypothesis 2: Political sophistication decreases campaign volatility.

Political disaffection is a third factor that is claimed to induce instability in voters' party preferences. Over the last two decades, several studies have pointed to the existence of a strong relationship between political dissatisfaction and voters' volatility. The notion of the frustrated floating voter was put forward by Zelle (1995). While the cognitive mobilization theory stresses the image of a rational and well-educated citizen whose relationship to parties is mainly grounded on instrumental considerations (e.g., Dalton, 1984), the frustrated floating voter denotes a model of a citizen who wants to preserve an affective positive relationship to his/her favourite party. If this party eventually proves to be unworthy of his/her trust, disappointment about that individual party may elicit a feeling of frustration that translates into general dissatisfaction with the party system and the political system (Zelle, 1995). According to Zelle, this kind of political disaffection stimulates electoral volatility; the frustrated voter would shift to another party in the subsequent elections in order to express his/her dissatisfaction with political actors and institutions. In other words, whenever a voter switches from party A to party B between two consecutive elections, this should not be interpreted as a sincere vote in favour of party $\mathrm{B}$, but rather as a protest vote against parties and the political system as a whole. "Thus, the frustrated floating voter does not primarily perform a positive change to the new party, but turns his back to his old party in a mood of protest" (Zelle, 1995: p: 332). As Zelle has pointed out, volatile voters display a lower level of trust in parties, a lower degree of satisfaction with democracy and a lower level of affection for their favourite party.

Using data from national elections studies in five countries (Australia, Canada, the Netherlands, the United Kingdom and the United States), Dalton and Weldon (2005) also observed that distrust in parties induced higher levels of electoral volatility. Similarly, in her study on the sources of voter's volatility at the 2007 French presidential and parliamentary elections, Muxel (2009) noticed that political disaffection was one of the main catalysts of vote switching. Electors with a low degree of trust in the French political system were more prone than other voters to change parties between two successive elections (Muxel, 2009). In the Belgian case as well, political dissatisfaction has 
been found to trigger party switching. Dassonneville (2012) showed that external political efficacy strongly correlated with both inter-election volatility and campaign volatility during the 2009 regional elections. Furthermore, trust in local and national institutions as well as external political efficacy emerged as good predictors of vote switching in the 2012 Belgian local elections (Dassonneville, Hooghe, \&Marien, 2014).

Rather than focussing on long-term attitudes linked to general disaffection such as trust in parties, satisfaction with democracy or external political efficacy, Soderlund (2008) examined whether or not voter's volatility could be explained by a short-term attitude, namely retrospective evaluations of party performances. He demonstrated that the probability of vote switching was strongly influenced by retrospective evaluations of performances of the party the respondent had voted for in the previous elections. Citizens tended to remain loyal to the party they had previously voted for if they thought that it had done a good job during the inter-election period, and conversely, voters were inclined to change parties if they considered that their previously endorsed party had performed poorly (Soderlund, 2008). Remarkably, the relationship between perceived party performances and vote switching remained robust even after controlling for the variables associated with general dissatisfaction with politics. According to Soderlund, this finding seems to indicate that shifts in voting behaviour should be interpreted as the products of rational judgments about past performances instead of being seen as symptoms of political frustration. This also means that disappointment about a particular party does not necessarily translate into general dissatisfaction with the political system, which contradicts Zelle's frustrated floating voter hypothesis (Soderlund, 2008). In their analysis of the determinants of party switching in 36 elections held in 22 advanced democracies, Dassonneville, Blais and Dejaeghere (2015) came to the same conclusion as that drawn by Soderlund. They pointed out that dissatisfaction with the party previously voted for significantly increased the probability of changing parties. By contrast, a general feeling of political dissatisfaction did not significantly affect the likelihood of vote switching. In sum, party switchers were not frustrated about politics in general, but they clearly were disappointed about the performances of the party they had voted for in the previous elections (Dassonneville et al., 2015).

Even though retrospective evaluation of party performances is claimed to be a good predictor of electoral volatility, we cannot include this "short-term" explanatory variable in our analysis because of the absence of data thereon ${ }^{3}$. Consequently, we devote our attention to "long-term" attitudes that allow to measure voter's level of political satisfaction. In previous work, researchers have mentioned four "long-term" attitudes influencing the probability of vote switching: affect towards the favourite party, trust in political actors and institutions, satisfaction with democracy and external political efficacy (Dalton \& Weldon, 2005; Dassonneville, 2012; Zelle, 1995). In the present article, we include in our model these four indicators of political satisfaction in order to test the validity of the frustrated floating voter hypothesis.

Hypothesis 3: Political satisfaction decreases campaign volatility.

${ }^{3}$ In the Parti Rep survey questionnaire, respondents were not asked to evaluate the past performances of the party they had voted for in the previous elections. 
Finally, voter's ideological profile is often argued to be one of the main determinants of electoral volatility. Scholars state that ideological extremeness reduces the probability of switching from one party to another between two successive elections as well as during the campaign (Crow, 2005; Dassonneville, 2012; Lisi, 2010; Van Der Meer et al., 2015). Voters with a radical ideological profile (i.e. those who place themselves to the far left or to the far right on the left-right axis) usually display a high degree of stability in their political opinions and tend to report strong partisan attachments. Hence, they are expected to remain loyal to the same party elections after elections (Crow, 2005; Dassonneville, 2012; Lisi, 2010; Van Der Meer et al., 2015). By contrast, citizens with a moderate ideological profile (i.e. those who place themselves close to the ideological centre) are thought to be less committed to a particular party and much more ambivalent to the different political alternatives that are available on the electoral market. As a consequence, they should be more inclined to change parties between two consecutive electoral contests and to switch their vote intention during the weeks preceding the elections. In line with these expectations, some recent studies have shown that the level of volatility was the highest among voters with moderate ideological orientations (Crow, 2005; Dassonneville, 2012; Lisi, 2010; Van Der Meer et al., 2015).

In the Belgian fragmented multiparty system, ideological spaces between the different political alternatives appear relatively small, since a large majority of the main parties (i.e. those represented in the federal parliament) exhibit a quite moderate ideological profile and are located close to the ideological centre (see Walgrave et al., 2010). Socialists and greens position themselves to the centre-left, Christian-democrats to the centre and liberals to the centre-right. Belgian electors with moderate ideological preferences are therefore located within the small ideological spaces defined by positions of the main parties on the left-right axis. Consequently, they have a plethora of possible party choices and should be inclined to change their mind in the weeks preceding the elections. Conversely, voters with radical ideological orientations are located outside the ideological spaces between the main political forces and most of the time, there is only one single party that is close to their position. Thus, they should be less prone to switch from one party to another during the campaign.

Hypothesis 4: Ideological extremeness decreases campaign volatility.

\section{Data and Operationalization}

Our study draws on data from the 2014 PartiRep Belgian Voter Survey which was conducted among a random sample of eligible voters from the two biggest regions of the country, namely Flanders and Wallonia ${ }^{4}$. This dataset contains individual-level information on respondents' political attitudes and voting choices in the federal, regional and European elections of May 25. The PartiRep survey had a two wave panel design; it consisted of a pre-electoral wave and a post-electoral wave. The pre-electoral wave took place between March 20 and May 17 and consisted of face-to-face interviews. It resulted ${ }^{4}$ There are three regions in Belgium: Flanders, Wallonia and Brussels. In the present article, Brussels is left out of our analysis, since Brussels citizens were not interviewed in the 2014 PartiRep Belgian Voter Survey. This panel survey was only conducted in the two other regions. 
in a total of 2019 interviews (1018 in Wallonia and 1001 in Flanders). The post-electoral wave with telephone interviews was conducted between the end of May and the end of June. A total of 1528 respondents (702 in Wallonia and 826 in Flanders) participated in this second wave.

Our dependent variable, campaign volatility, can only be operationalized by means of panel survey data that allow to compare respondent's vote intention at the start of the campaign with his/her actual voting choice on Election Day. The panel design of the PartiRep survey enables us to determine whether or not respondents changed their mind during the campaign. In the pre-electoral interview, they were asked to indicate which party they intended to vote for at the federal elections, and in the post-electoral interview, they were asked to mention which party they had eventually chosen on Election Day. By comparing the vote intention reported in the pre-electoral wave with the actual electoral behaviour reported in the post-electoral wave, we can distinguish between two groups of respondents: stable voters and campaign switchers. Stable voters are those respondents who reported a vote intention for a given party at the beginning of the campaign and who eventually cast a ballot for that party in the federal elections. Campaign switchers are those who expressed a vote intention in favour of a given party at the launch of the campaign but who then cast a vote for another party at the federal elections. The variable "campaign volatility" is dichotomous; it takes the value 1 for campaign switchers and the value 0 for stable voters.

Table 1 indicates that about a third (32.8\%) of the respondents reported having changed their vote intention during the months preceding the 2014 federal elections. Interestingly, this level of campaign volatility turns out to have been relatively high when compared to figures observed in other Western countries such as Canada, Germany, Sweden, Switzerland or the United States (Blais, 2004; Granberg \& Holmberg, 1991; Lachat, 2007).

The present study aims to identify the factors that can account for stability and change of vote intentions during the 2014 Belgian federal election campaign. As explained above (see section "Theoretical framework"), our hypotheses focus on four potential predictors of campaign volatility: strategic considerations, political sophistication, political satisfaction and ideological extremeness. Hypothesis 1 posits that a voter can decide to switch his/her vote intention due to tactical considerations related to his/her perception about the coalition potential of the party he/she intended to vote for at the launch of the campaign. In order to test this hypothesis, we include in our model the variable "Perceived coalition potential of the party the respondent planned to vote for in the pre-electoral wave" as an independent variable. In the pre-electoral interview, respondents were asked to evaluate how much of a chance the party they intended to vote for had of joining the federal governmental coalition after the elections. They as-

Table 1. Proportion of campaign switchers in the 2014 Belgian federal elections.

\begin{tabular}{cccc}
\hline Stable & Volatile & Total & $\mathbf{n}$ \\
\hline $67.2 \%$ & $32.8 \%$ & $100 \%$ & 1316 \\
\hline
\end{tabular}


sessed this coalition potential on an 11-point scale where 0 meant "The party has no chance of entering the governmental coalition" and 10 meant "The party has a very good chance of entering the governmental coalition".

The second explanatory factor, political sophistication, is a broad and complex concept which encompasses two distinct dimensions: cognitive skills and interest in politics (Lachat, 2007). Hence, political sophistication can be operationalized by means of a wide range of indicators such as political knowledge, internal political efficacy, political interest, the degree of campaign attention, media exposure or political participation (Dassonneville, 2012; Lachat, 2007). In our analysis, we make use of three distinct indicators for measuring voter's level of sophistication, namely political knowledge, political interest and campaign attention. We construct an index of political knowledge that corresponds to the respondent' score on five political knowledge questions asked in the PartiRep survey. This score takes values ranging from 0 ("no political knowledge at all”) to 5 ("high political knowledge"). The variable "political interest" consists of the self-reported level of interest in politics on an 11-point scale where 0 means "no interest at all" and 10 means "Very much interest". In order to measure the degree of campaign attention, respondents were asked to indicate how often they had paid attention to political information in the media (newspapers, TV and radio) during the campaign. Respondents gave an answer on a 4-point scale where 0 means "Never", 1 "One or several time(s) a month", 2 "One or several time(s) a week" and 3 "Every day".

The third explanatory factor, political satisfaction, also encompasses many distinct dimensions and, as a result, it can be operationalized by means of a large number of indicators (Soderlund, 2008; Zelle, 1995). Our model incorporates four independent variables designed to assess respondent's level of political satisfaction: political trust, affect towards the preferred party, satisfaction with democracy and external political efficacy. Political trust is measured through the average score for self-reported degree of trust in a series of institutions and political actors: the justice, the police, media, political parties, the regional government, the regional parliament, the federal government, the federal parliament, social movements, politicians, and the European Union. For each of these 11 institutions, respondents gave a value on an 11-point scale where 0 means "No trust at all" and 10 means "Complete trust". In order to assess affect directed to the favourite party, we look at respondent' self-reported degree of affection for each political party on an 11-point sympathy scale. The highest sympathy score given by the respondent to any one out of all Belgian parties represents his/her level of affection for his/her preferred party. Satisfaction with democracy consists of respondent' self-reported degree of satisfaction with the Belgian democratic process on a 4-point scale where 0 means "not satisfied at all" and 3 means "highly satisfied". The variable "external political efficacy" is constructed by means of the average score on 14 items that deal with the feeling of external political efficacy (see these items in Appendix). This average score may take values ranging from 0 ("low political efficacy") to 4 ("high political efficacy”).

The last independent variable, "ideological extremeness", is constructed on the basis 
of the respondent's left-right self-placement on an 11-point scale where 0 means "the left" and 10 means "the right". For each respondent, we calculated the distance between his/her self-reported position on the left-right axis and the ideological centre (i.e. the position 5 on that axis). Thus, the level of ideological extremeness is ranging from 0 (when the position 5 was reported) to 5 (when the position 0 or 10 was reported).

Furthermore, we include in our model some control variables: age, gender, the level of education and party identification ${ }^{5}$. First, we examine the effect of age which is seen as one of the best predictors of electoral volatility. According to the socialization model of the Michigan school (Campbell et al., 1960), young citizens tend to frequently change their party preferences because of the weakness of their partisan attachments and their high susceptibility to "short-term" forces. By contrast, older voters usually develop a strong feeling of party identification making them more loyal and more stable in their voting behaviour. A large number of studies demonstrate that young voters are more likely than their elders to switch from one party to another both between two successive elections and during the campaign (e.g. Converse, 1969; Dassonneville, 2012; Kuhn, 2009; Muxel, 2009; Soderlund, 2008; but see Van Der Meer et al., 2015).

Second, we control for gender. In most studies, this variable has been found to have no significant effect on volatility (e.g. Dassonneville, 2012; Kuhn, 2009; Soderlund, 2008; Tiberj, 2015; Walgrave et al., 2010). Nevertheless, gender sometimes affects the stability of party preferences; in some cases, women proved to be more volatile than men (e.g. Hayes \& McAllister, 2001) while in other cases, men were more inclined to change parties (e.g. Van Der Meer et al., 2015).

Our third socio-structural variable, the level of education, is often claimed to influence voter's volatility. The cognitive mobilization theory developed by Dalton holds that a high level of education leads to uncertainty and instability in electoral preferences (Dalton, 1984; Dalton et al., 2000). While less educated voters rely on their party affiliation as a heuristic cue to guide their voting decision, highly educated citizens don't have to use such a cue, since they are able to make their own independent electoral choices on the basis of short-term factors such as issues and evaluation of past performances. As a result, volatility is expected to be higher among well-educated voters (Dalton, 1984, 2007; Dalton et al., 2000).

In addition to these socio-demographic characteristics, we also control for party identification, which is argued to form a barrier against voter's volatility. In their seminal book The American Voter, Campbell et al. (1960) stressed the stabilizing effect of partisanship on electoral behaviour by showing that voters who identified with a particular party almost invariably remained loyal to that party election after election. By contrast, independents were found to be considerably more inclined to switch parties from one election to another (Campbell et al., 1960). In line with these early findings, a large number of recent studies clearly demonstrate that voters who report no partisan attachment are much more volatile than party identifiers (e.g. Blumenstiel \& Plischke, 2015; Crow, 2005; Dalton, 2013; Dassonneville \& Dejaeghere, 2014; Granberg \& Holm-

${ }^{5}$ For the coding details of the control variables, see Appendix. 
berg, 1991; Lachat, 2007; Lisi, 2010; Soderlund, 2008).

\section{Results}

To start with, we perform some bivariate analyses. First, we try to determine whether campaign volatility is triggered by strategic considerations. We do so by comparing how stable voters and campaign switchers evaluated the coalition potential of the party for which they expressed a vote intention at the beginning of the campaign. As can be read from Table 2, the results of this comparison lend support for hypothesis 1 . At the start of the campaign, stable voters thought that the party they intended to support had a relatively good chance of joining the federal governmental coalition after the elections (mean perceived coalition potential $=7.06$ out of 10 ). Campaign switchers, on the other hand, considered that the party they planned to vote for at the launch of the campaign displayed a lower chance of gaining office (mean perceived coalition potential $=5.48$ out of 10). The difference between stable voters and switchers in terms of perceived coalition potential is statistically significant.

Second, we investigate the relationship between political sophistication and campaign volatility, by looking at differences between stable voters and switchers with respect to their levels of political knowledge, political interest and campaign attention. As can be seen in Table 3, campaign switchers are less interested in politics, less attentive to political information and less knowledgeable about the political system, which is in line with our expectations. For each of these three variables, the difference between the two groups of respondents reaches the conventional level of statistical significance. Thus, hypothesis 2 can be totally confirmed.

Third, we examine whether or not there is a link between political disaffection and campaign volatility. We make use of four different indicators in order to compare the average level of political satisfaction of switchers with that of stable voters. The results of this comparison (reported in Table 4) give credit to hypothesis 3, as they clearly show that compared to stable voters, campaign switchers exhibit a lower level of satis-

Table 2. Strategic considerations and campaign volatility in the 2014 Belgian federal elections.

\begin{tabular}{lcccc}
\hline & $\begin{array}{c}\text { Stable voters } \\
\text { (mean score) }\end{array}$ & $\begin{array}{c}\text { Campaign switchers } \\
\text { (mean score) }\end{array}$ & T-value & Sign. \\
\hline $\begin{array}{l}\text { Perceived Coalition Potential of the } \\
\begin{array}{l}\text { Party the Respondent Planned to } \\
\text { Vote for in Wave 1 }\end{array}\end{array}$ & 7.06 & 5.48 & 9.29 & 0.000 \\
\hline
\end{tabular}

Table 3. Political sophistication and campaign volatility in the 2014 Belgian federal elections.

\begin{tabular}{lcccc}
\hline & Stable voters(mean score) & $\begin{array}{c}\text { Campaign switchers } \\
\text { (mean score) }\end{array}$ & T-value & Sign. \\
\hline Political Interest & 5.54 & 4.45 & 6.96 & 0.000 \\
Political Knowledge & 2.41 & 2.17 & 2.86 & 0.004 \\
Campaign Attention & 2.15 & 1.95 & 3.35 & 0.001 \\
\hline
\end{tabular}


Table 4. Political satisfaction and campaign volatility in the 2014 Belgian federal elections.

\begin{tabular}{lcccc}
\hline & $\begin{array}{c}\text { Stable voters } \\
\text { (mean score) }\end{array}$ & $\begin{array}{c}\text { Campaign switchers } \\
\text { (mean score) }\end{array}$ & T-value & Sign. \\
\hline Political Trust & 5.27 & 4.83 & 5.09 & 0.000 \\
External Political Efficacy & 1.84 & 1.66 & 5.41 & 0.000 \\
Affection for the Favourite Party & 7.78 & 7.01 & 7.79 & 0.000 \\
Satisfaction with Democracy & 1.76 & 1.67 & 2.15 & 0.031 \\
\hline
\end{tabular}

Table 5. Ideological extremeness and campaign volatility in the 2014 Belgian federal elections.

\begin{tabular}{lcccc}
\hline & $\begin{array}{c}\text { Stable voters } \\
\text { (mean score) }\end{array}$ & $\begin{array}{c}\text { Campaign switchers } \\
\text { (mean score) }\end{array}$ & T-value & Sign. \\
\hline Ideological extremeness & 1.59 & 1.39 & 2.30 & 0.021 \\
\hline
\end{tabular}

faction with democracy, a lower degree of trust in institutions and political actors, a lower level of external political efficacy and a lower degree of affection for their favourite party. These differences between stable voters and switchers are statistically significant for each of the four indicators.

Finally, we attempt to determine whether ideological extremeness significantly correlates with campaign volatility. To this end, we compare the average degree of ideological extremeness of switchers with that of stable voters (see Table 5). Results seem to confirm our hypothesis 4 , since the average ideological profile of switchers proves to be more moderate than that of stable voters. The difference between the two groups of respondents in terms of ideological extremeness achieves statistical significance.

After having conducted these preliminary bivariate analyses, we carry out a multivariate analysis; we regress campaign volatility on all the independent and control variables. Given that the dependent variable is dichotomous, we perform a binary logistic regression in order to test our hypotheses. The results of our multivariate analysis are displayed in Table 6. At first glance, it appears that most coefficients are in the expected direction.

First, regression results provide compelling evidence in support of hypothesis 1 which suggests that strategic considerations can cause voters to change their vote preferences during an election campaign. Indeed, the probability of campaign volatility is significantly influenced by voters' perceptions about the coalition potential of the party they planned to vote for at the launch of the campaign. The higher this perceived coalition potential, the lower is the probability that the voter changes his/her vote intention in the weeks preceding the elections. In other words, if the voter believes that the party he/she intends to vote for at the start of the campaign is capable of joining the governmental coalition after the elections, he/she will tend to remain stable in his/her vote preference during the campaign and will probably cast a ballot for that party on Election Day. In contrast, if the voter considers that the party he/she plans to support exhibits a low coalition potential, he/she will be considerably more likely to change his/ 
Table 6. The determinants of campaign volatility in the 2014 Belgian federal elections (binary logistic regression).

\begin{tabular}{llc}
\hline Variables & \multicolumn{1}{c}{ B } & SE \\
\hline Intercept & $2.909^{* * *}$ & 0.487 \\
Gender $(0=$ Male; $=$ Female) & $0.387^{* *}$ & 0.143 \\
Age & $-0.014^{* *}$ & 0.005 \\
Level of Education & 0.029 & 0.079 \\
Party Identification & $-0.679^{* * *}$ & 0.146 \\
Perceived Coalition Potential of the Party the & $-0.194^{* * *}$ & 0.027 \\
Respondent Planned to Vote for in Wave 1 & 0.014 & 0.053 \\
Political Knowledge & $-0.083^{* *}$ & 0.032 \\
Political Interest & 0.058 & 0.081 \\
Campaign Attention & $-0.319^{*}$ & 0.160 \\
External Political Efficacy & 0.018 & 0.066 \\
Political Trust & -0.013 & 0.122 \\
Satisfaction with Democracy & $-0.107^{*}$ & 0.048 \\
Affection for the Favourite Party & -0.024 & 0.050 \\
Ideological Extremeness & 0.208 & \\
Nagelkerke $\mathbf{R}^{2}$ & 1316 & \\
N & & \\
\hline
\end{tabular}

Coefficients are unstandardized regression coefficients. ${ }^{*} p<0.05 ;{ }^{* *} p<0.01 ;{ }^{* * *} p<0.001$.

her vote preference and to shift to another party that seems to have a better chance of gaining office. Since log odds coefficients of a binary logistic regression are quite hard to interpret, Figure 1 graphically presents the estimated effect of the perceived coalition potential of the party the respondent planned to vote for on the probability of campaign volatility. The graph shows that a high perceived coalition potential decreases the likelihood of changing one's vote intention in the last weeks before the election.

As can be seen in Table 6, our analysis also seems to partially confirm the hypothesis that political sophistication leads to higher levels of stability in vote preferences (H2). In line with our expectations, political interest has a significant effect on campaign volatility and this effect is in the negative direction. As Figure 2 illustrates, the higher the level of political interest, the more stable will be the vote intention. This finding does contradict the cognitive mobilization thesis (Dalton, 1984), but is consonant with the traditional floating voter thesis of the Columbia school which holds that the level of volatility is the highest among uninformed and uninterested voters (Berelson et al., 1963; Lazarsfeld et al., 1968). Nevertheless, hypothesis 2 can only be partially confirmed, because none of the two other indicators of political sophistication (campaign attention and political knowledge) is significantly associated with campaign switching.

Similarly, the hypothesis that shifts in vote intentions can be attributed to political disaffection (H3) is partially confirmed, since two out of the four indicators of political 


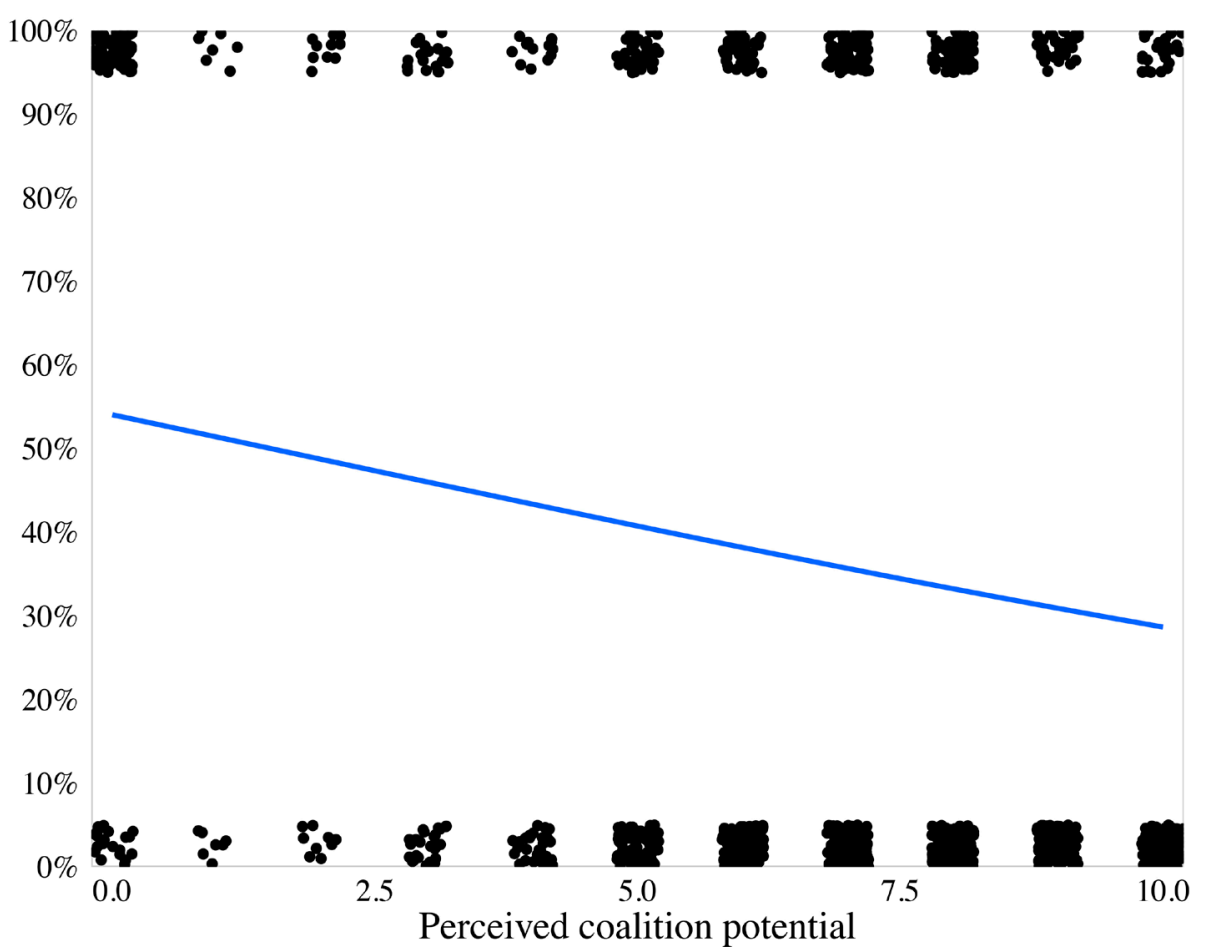

Note: Predictions with all covariates set at their sample means. Predictions are based on estimates presented in Table 6.

Figure 1. Predicted probability of campaign volatility by perceived coalition potential of the party the respondent planned to vote for at the start of the campaign.

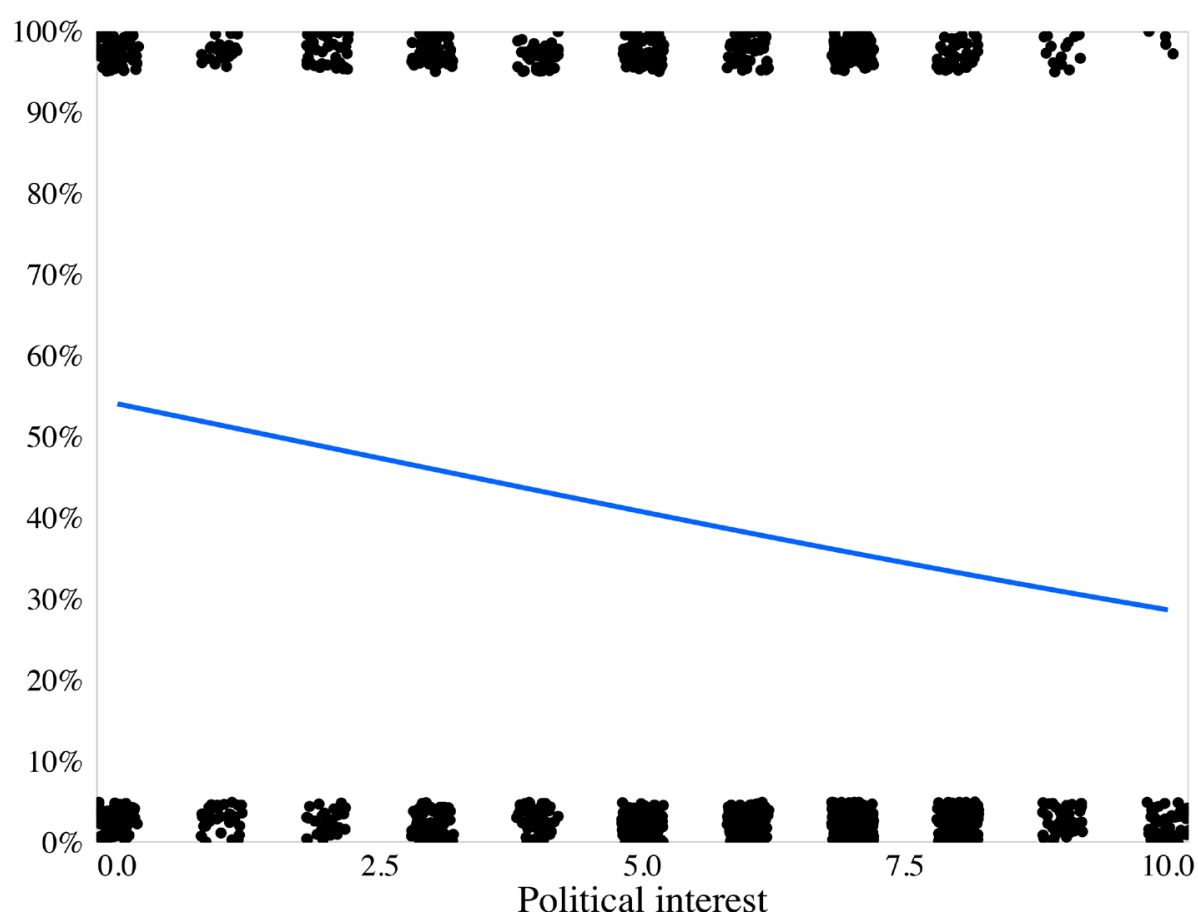

Note: Predictions with all covariates set at their sample means. Predictions are based on estimates presented in Table 6.

Figure 2. Predicted probability of campaign volatility by level of political interest. 
satisfaction (external political efficacy and affection for the favourite party) significantly correlate with campaign volatility. As expected, voters with a low level of external political efficacy are more prone than other voters to switch from one party to another during the weeks preceding the elections. Figure 3 plots the estimated effect of external political efficacy on the probability of campaign volatility. Furthermore, we may point at the presence of a negative relationship between affection for the favourite party and campaign volatility. The higher the degree of affection for one's most preferred party, the lower will be the probability of changing one's vote intention during the campaign. It is clear from Figure 4 that a high level of affect towards one's favourite party contributes to the stability of vote preferences. By contrast, the two other variables measuring political satisfaction (political trust and satisfaction with democracy) have no significant impact on campaign switching.

As evident from Table 6, regression results lend no support for the hypothesis that voters with a radical ideological profile are less likely than moderate voters to change their mind in the last weeks before Election Day (H4). Admittedly, the effect of ideological extremeness on campaign volatility is in the expected negative direction, but it is far from achieving statistical significance.

Regarding the control variables, results indicate that party identification significantly reduces the probability of switching one's vote intention during the campaign. Voters who report no partisan attachment are much more inclined than party identifiers to change their mind in the weeks preceding the elections. Moreover, one may observe that two socio-demographic characteristics, gender and age, significantly influence

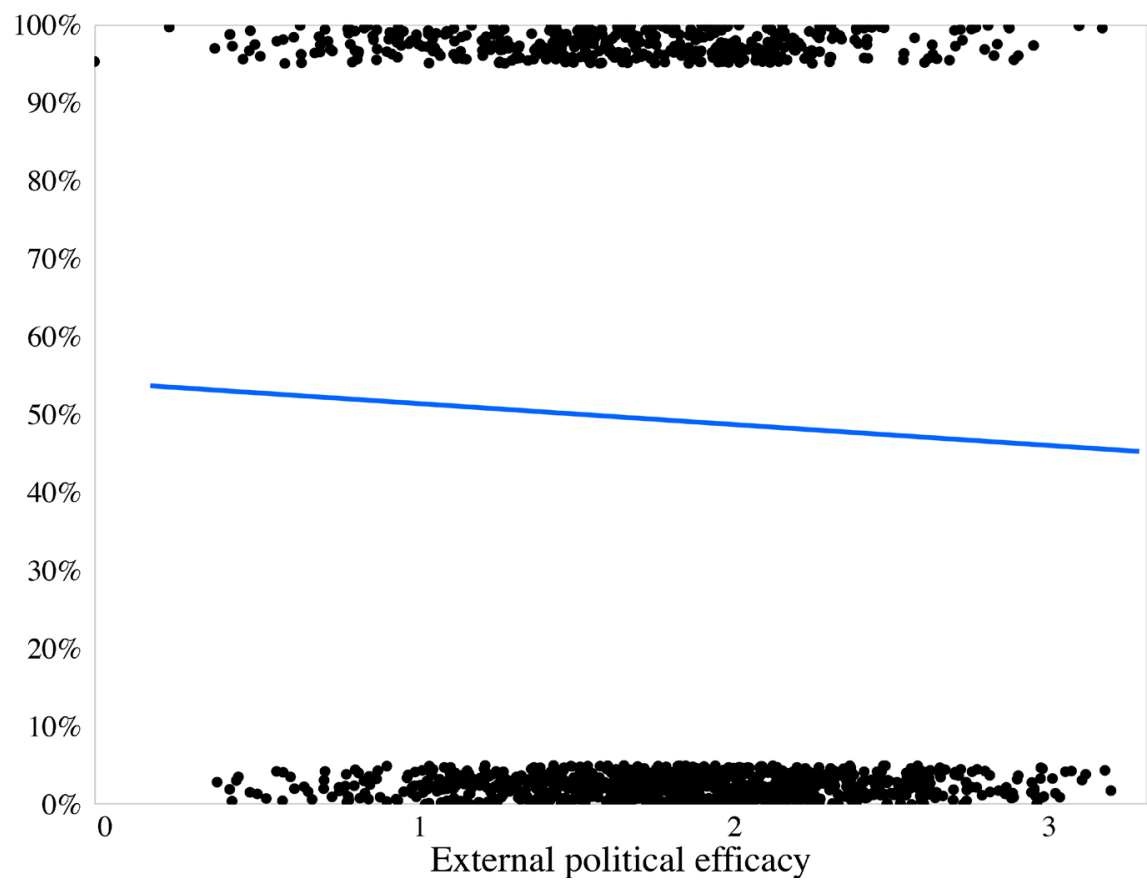

Note: Predictions with all covariates set at their sample means. Predictions are based on estimates presented in Table 6.

Figure 3. Predicted probability of campaign volatility by level of external political efficacy. 


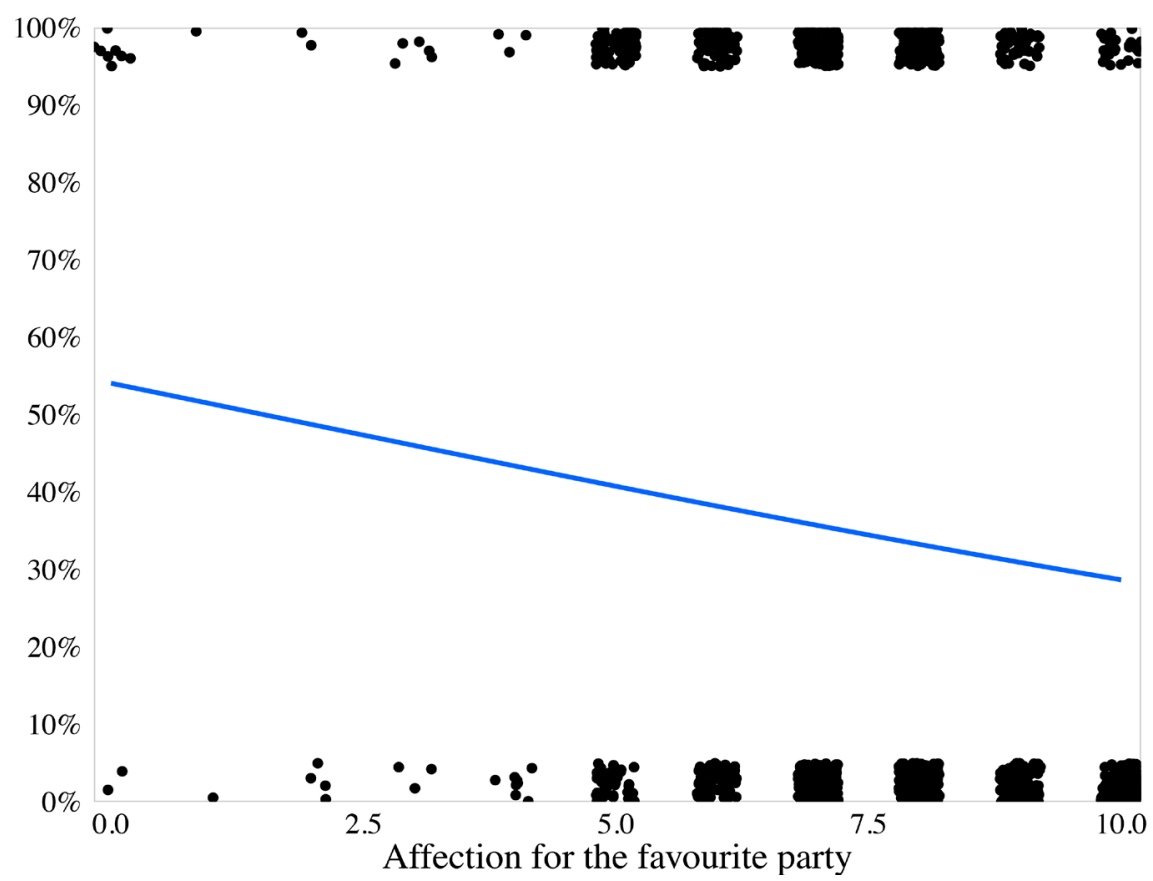

Note: Predictions with all covariates set at their sample means. Predictions are based on estimates presented in Table 6.

Figure 4. Predicted probability of campaign volatility by degree of affection for the favourite party.

campaign switching. Interestingly, women prove to be somewhat more volatile than men. Unsurprisingly, age has a stabilizing impact on voters' party preferences; young voters are more prone than their elders to switch parties in the weeks preceding the elections. For the sake of completeness, it is worth noting that the last socio- demographic variable, namely the level of education, is not significantly related to campaign volatility.

\section{Conclusion}

Over the past few decades, Belgian politics has been marked by an increasing electoral instability. The growing uncertainty of voters' party preferences has not only led to a rise in the level of inter-election volatility (i.e. vote switching between two consecutive elections), but it has also translated into an increase in the level of campaign volatility (i.e. shifts in vote intentions during the campaign). The data from the PartiRep Belgian Voter Survey reveal that about a third of the respondents have switched their vote intention in the weeks preceding the 2014 federal elections.

The present article precisely aimed to identify the causes of stability and change in vote preferences during the 2014 federal election campaign. To this end, we have tested four different types of potential explanations for campaign volatility and three out of the four hypotheses have received at least partial empirical support. First, the results of our analysis clearly demonstrate that strategic considerations can induce campaign volatility. Indeed, it appears that some voters have decided to change their vote preferences in the weeks preceding the elections, because they thought that the party they 
planned to vote for at the start of the campaign had little or no chance of entering the federal governmental coalition. Second, we point at the existence of a strong negative relationship between the level of political interest and campaign volatility; voters who are not interested in politics are more inclined than highly interested voters to switch from one party to another during the campaign. Third, our results partially confirm the frustrated floating voter hypothesis which assumes that campaign volatility is triggered by political disaffection. As expected, voters with a low degree of affection for their favourite party are found to be much more volatile than those who maintain an affective positive relationship to their most preferred party. In a similar vein, we show that voters with a low level of external political efficacy are more prone than other voters to switch parties in the weeks preceding the elections. Finally, the results of our study lead us to reject the last hypothesis which posits that ideological extremeness decreases the chance of being a campaign switcher.

In sum, we can conclude that campaign switchers are more likely to be drawn from the ranks of young voters who factor strategic considerations into their vote decision and who display a low level of political interest, a low degree of affection for their favourite party and a low level of external political efficacy. The interpretation of our results is not straightforward, since some of our findings are somewhat paradoxical. On the one hand, the fact that campaign volatility can be partially attributed to strategic considerations is consonant with the "positive" image of the modern floating voter put forward by the cognitive mobilization theory. In this optimistic perspective, the volatile voter would be a young and well-educated voter who would exhibit a high level of political sophistication and who would make rational voting choices on the basis of "short-term" factors such as issues, candidate evaluations, retrospective judgments about government performances and strategic considerations (Dalton et al., 2000; Franklin, Mackie, \& Valen, 2009; Habert \& Lancelot, 1988; Rose \& McAllister, 1986). On the other hand, we find campaign switchers to be uninterested in politics and dissatisfied with the political system. This observation accords with the "negative" image of an apathetic and distrustful volatile voter, which has been sketched by the traditional floating voter theory (Berelson et al., 1963) and the frustrated floating voter theory (Zelle, 1995). Given these paradoxical findings, it seems that further work is required to determine whether shifts in vote preferences during an election campaign must be considered as the products, of strategic calculations, as the consequences of a lack of political sophistication, or as the symptoms of political frustration.

\section{References}

Albright, J. (2009). Does Political Knowledge Erode Party Attachments? A Review of the Cognitive Mobilization Thesis. Electoral Studies, 28, 248-260. http://dx.doi.org/10.1016/j.electstud.2009.01.001

Bartolini, S., \& Mair, P. (1990). Identity, Competition and Electoral Availability. Colchester: ECPR Press.

Berelson, B., Lazarsfeld, P., \& McPhee, W. (1963). Voting: A Study of Opinion Formation in a Presidential Campaign (2nd ed.). Chicago, IL: University of Chicago Press. 
Bischoff, C. (2013). Electorally Unstable by Supply or Demand?-An Examination of the Causes of Electoral Volatility in Advanced Industrial Democracies. Public Choice, 156, 537-561. http://dx.doi.org/10.1007/s11127-011-9910-z

Blais, A. (2004). How Many Voters Change Their Minds in the Month Preceding an Election? PS: Political Science and Politics, 38, 801-803.

Blais, A., Nadeau, R., Gidengil, E., \& Nevitte, N. (2001). Measuring Strategic Voting in Multiparty Plurality Elections. Electoral Studies, 20, 343-352. http://dx.doi.org/10.1016/S0261-3794(00)00017-2

Blumenstiel, J. E., \& Plischke, T. (2015). Changing Motivations, Time of the Voting Decision, and Short-Term Volatility-The Dynamics of Voter Heterogeneity. Electoral Studies, 37, 28-40. http://dx.doi.org/10.1016/j.electstud.2014.11.003

Boy, D., \& Dupoirier, E. (1990). L'électeur est-il stratège? In D. Boy, \& N. Mayer (Eds.), L'électeur français en question (pp. 175-196). Paris: Presses de la FNSP.

Campbell, A., Converse, P., Miller, W., \& Stokes, D. (1960). The American Voter. New York: Wiley.

Converse, P. (1962). Information Flow and the Stability of Partisan Attitudes. The Public Opinion Quarterly, 26, 578-599. http://dx.doi.org/10.1086/267129

Converse, P. (1969). Of Time and Partisan Stability. Comparative Political Studies, 2, 139-171. http://dx.doi.org/10.1177/001041406900200201

Cox, G. (1997). Making Votes Count. Cambridge: Cambridge University Press. http://dx.doi.org/10.1017/CBO9781139174954

Crewe, I., \& Denver, D. (1985). Electoral Change in Western Democracies: Patterns and Sources of Electoral Volatility. London: Routledge.

Crow, D. (2005). Crossing Party Lines: Volatility and Ticket Splitting in Mexico (1994-2000). Bulletin of Latin American Research, 24, 1-22. http://dx.doi.org/10.1111/j.0261-3050.2005.00122.x

Dalton, R. (1984). Cognitive Mobilization and Partisan Dealignment in Advanced Industrial Democracies. The Journal of Politics, 46, 264-284. http://dx.doi.org/10.2307/2130444

Dalton, R. (2007). Partisan Mobilization, Cognitive Mobilization and the Changing American Electorate. Electoral Studies, 26, 274-286. http://dx.doi.org/10.1016/j.electstud.2006.04.009

Dalton, R. (2013). The Apartisan American: Dealignment and Changing Electoral Politics. Washington DC: CQ Press.

Dalton, R., McAllister, I., \& Wattenberg, M. (2000). The Consequences of Partisan Dealignment. In R. Dalton, \& M. Wattenberg (Eds.), Parties Without Partisans (pp. 37-63). Oxford: Oxford University Press.

Dalton, R., \& Weldon, S. (2005). Public Images of Political Parties: A Necessary Evil? West European Politics, 28, 931-951. http://dx.doi.org/10.1080/01402380500310527

Dassonneville, R. (2012). Electoral Volatility, Political Sophistication, Trust and Efficacy: A Study on Changes in Voter Preferences during the Belgian Regional Elections of 2009. Acta Politica, 47, 18-41. http://dx.doi.org/10.1057/ap.2011.19

Dassonneville, R., Blais, A., \& Dejaeghere, Y. (2015). Staying with the Party, Switching or Exiting? A Comparative Analysis of Determinants of Party Switching and Abstaining. Journal of Elections, Public Opinion and Parties, 25, 387-405. http://dx.doi.org/10.1080/17457289.2015.1016528

Dassonneville, R., Hooghe, M., \& Marien, S. (2014). Loyauté partisane et volatilité lors des élections locales. In J.-B. Pilet, R. Dassonneville, M. Hooghe, \& S. Marien (Eds.), L'électeur 
local. Le comportement électoral au scrutin communal de 2012 (pp. 27-50). Brussels: Editions de l'Université de Bruxelles.

Dassonneville, R., \& Dejaeghere, Y. (2014). Bridging the Ideological Space: A Cross-National Analysis of the Distance of Party Switching. European Journal of Political Research, 53, 580-599. http://dx.doi.org/10.1111/1475-6765.12049

Drummond, A. (2006). Electoral Volatility and Party Decline in Western Democracies: 1970-1995. Political Studies, 54, 628-647. http://dx.doi.org/10.1111/j.1467-9248.2006.00617.x

Franklin, M., Mackie, T., \& Valen, H. (2009). Electoral Change. Responses to Evolving Social and Attitudinal Structures in Western Countries (2nd ed.). Colchester: ECPR Press.

Granberg, D., \& Holmberg, S. (1990). The Berrelson Paradox Reconsidered. Intention-Behavior Changers in U.S. and Swedish Election Campaigns. The Public Opinion Quarterly, 54, 530-550. http://dx.doi.org/10.1086/269226

Granberg, D., \& Holmberg, S. (1991). Election Campaign Volatility in Sweden and the United States. Electoral Studies, 10, 208-230. http://dx.doi.org/10.1016/0261-3794(91)90013-I

Habert, P., \& Lancelot, A. (1988). L'émergence d'un nouvel électeur. In Les élections législatives de 1988 (pp. 8-15). Paris: Le Figaro-Etudes Politiques.

Hayes, B., \& McAllister, I. (2001). Women, Electoral Volatility and Political Outcomes in Britain. European Journal of Marketing, 35, 971-983. http://dx.doi.org/10.1108/EUM0000000005955

Inglehart, R. (1977). The Silent Revolution. Changing Values and Political Styles among Western Publics. Princeton, NJ: Princeton UniversityPress.

Jaffre, J., \& Chiche, J. (1997). Mobilité, volatilité, perplexité. In D. Boy, \& N. Mayer (Eds.), L'électeur a ses raisons (pp. 285-325). Paris: Presse de Sciences Po.

Kuhn, U. (2009). Stability and Change in Party Preference. Swiss Political Science Review, 15, 463-494. http://dx.doi.org/10.1002/j.1662-6370.2009.tb00142.x

Lachat, R. (2007). A Heterogeneous Electorate. Political Sophistication, Predisposition Strength and the Voting Decision Process. Baden-Baden: Nomos. http://dx.doi.org/10.5771/9783845204895

Lazarsfeld, P., Berelson, B., \& Gaudet, H. (1968). The People's Choice: How the Voter Makes up His Mind in a Presidential Campaign (3rd ed.). New-York: Columbia University Press.

Lipset, S. M., \& Rokkan, S. (1967). Party Systems and Voter Alignments: Cross-National Perspectives. New York: Free Press.

Lisi, M. (2010). The Consequences of Cognitive Mobilization in Comparative Perspective: Political Sophistication and Voting Behavior in Old and New Democracies. Conference paper presented at APSA 2010: The 106th Annual Meeting of the American Political Science Association, Washington DC.

Mair, P. (2005). Democracy beyond Parties. Working Paper, Irvine, CA: Centre for the Study of Democracy.

Marthaler, S. (2008). The Paradox of the Politically Sophisticated Partisan: The French Case. West European Politics, 31, 937-959. http://dx.doi.org/10.1080/01402380802234607

McGregor, R. (2012). Voter Sincerity and the Time-of-Voting-Decision. Electoral Studies, 31, 715-725. http://dx.doi.org/10.1016/j.electstud.2012.07.002

Muxel, A. (2009). Loyautés, mobilités, abstentions. In B. Cautrès, \& A. Muxel (Eds.), Comment les électeurs font-ils leur choix? Le Panel électoral français 2007 (pp. 45-75). Paris: Presses de la FNSP.

Pedersen, M. (1979). The Dynamics of European Party Systems: Changing Patterns of Electoral Volatility. European Journal of Political Research, 7, 1-26. 
http://dx.doi.org/10.1111/j.1475-6765.1979.tb01267.x

Rose, R., \& McAllister, I. (1986). Voters Begin to Choose. From Closed-Class to Open Elections in Europe. London: Sage.

Soderlund, P. (2008). Retrospective Voting and Electoral Volatility: A Nordic Perspective. Scandinavian Political Studies, 31, 217-240. http://dx.doi.org/10.1111/j.1467-9477.2008.00203.x

Tiberj, V. (2015). Qui changent et pourquoi? Stabilité et évolution des opinions dans la France des années 2010. Conference paper presented at AFSP 2015: 13th Congress of the Association Française de Science Politique, Aix-en-Provence.

Van der Meer, T., Van Elsas, E., Lubbe, R., \& Van der Brug, W. (2015). Are Volatile Voters Erratic, Whimsical or Seriously Picky? A Panel Study of 58 Waves into the Nature of Electoral Volatility (The Netherlands 2006-2010). Party Politics, 21, 100-114.

http://dx.doi.org/10.1177/1354068812472570

Walgrave, S., Lefevere, J., \& Hooghe, M. (2010). Volatilsoucapricieux? La modification des préférences électorales au cours de la campagne. In K. Deschouwer, P. Delwit, M. Hooghe, \& S. Walgrave (Eds.), Les voix du peuple (pp. 25-42). Brussels: Editions de l'Université de Bruxelles.

Zelle, C. (1995). Social Dealignment versus Political Frustration: Contrasting Explanations of the Floating Vote in Germany. European Journal of Political Research, 27, 319-345.

http://dx.doi.org/10.1111/j.1475-6765.1995.tb00473.x 


\section{Appendix}

\section{Coding details of the independent variables}

Gender: Male $=0$; female $=1$

Age: In years calculated by distracting the reported year of birth from 2014 (the year that survey was conducted in).

Level of education: Respondent's level of education is a categorical variable coded as follows. No degree or elementary school degree $=0$; unfinished high school degree $=1$; finished high school degree $=2$; higher education or university degree $=3$.

Party identification: Party id is a dummy variable; it takes the value 1 for respondents who feel close to a particular party and the value 0 for other voters.

Perceived coalition potential of the party the respondent planned to vote for in wave 1: In the pre-electoral interview conducted at the start of the campaign, respondents were asked to evaluate how much of a chance the party they planned to vote for had of joining the federal government after the elections. They gave a value on an 11-point scale where 0 meant "No chance of entering the federal coalition" and 10 meant "A very good chance of entering the federal coalition".

Political interest: Self-reported level of interest in politics on an 11-point scale where 0 means "no interest at all" and 10 means "very much interest".

Political knowledge: Respondent' score on five knowledge questions asked in the PartiRep survey. Scores were thus ranging from 0 ("no knowledge") to 5 ("high knowledge").

Campaign attention: The survey questionnaire allows us to assess the level of campaign attention, as it contains the following question: How often did you pay attention to political information in the media (newspapers, radio and TV) during the election campaign? Four options were offered to respondents: never (coded 1); one or several time(s) a month (coded 1); one or several time(s) a week (coded 2); every day (coded $3)$.

Ideological extremeness: This variable is constructed on the basis of the respondent's left-right self-placement on an 11-point scale where 0 means "the left" and 10 means "the right". For each respondent, we calculated the distance between his/her self-reported position on the left-right continuum and the ideological centre (i.e. the value 5 on that continuum). Hence, the variable "ideological extremeness" takes values ranging from 0 (when 5 was reported) to 5 (when 0 or 10 was reported).

Political trust: This variable consists of the respondent's average score for self-reported level of trust in a series of political actors and institutions: the justice, the police, media, political parties, the regional government, the regional parliament, the federal government, the federal parliament, social movements, politicians, and the European Union. For each institution, respondents gave a score on an 11-point scale where 0 meant "No trust at all" and 10 meant "Complete trust".

Affection for the favourite party: Respondents were asked to indicate their degree of affection for each political party on an 11-point sympathy scale. The highest score given by a respondent to any one out of all parties represents his/her degree of affection 
for his/her favourite party.

Satisfaction with democracy: Self-reported level of satisfaction with the democratic process on a 4-point scale with values ranging from 0 ("not satisfied at all") to 3 ("highly satisfied").

External political efficacy: This variable consists of the respondent's average score on 14 items dealing with external political efficacy.

- During the election campaign, parties make many promises, but eventually, nothing happens anyway.

- An average citizen may have an impact on politics and what the government is doing.

- Voting makes no sense; parties do what they want anyway.

- Political parties offer clear and differentiated electoral platforms.

- In my country, politicians are capable of solving problems.

- International politics is capable of solving problems.

- If a sufficient number of people like me give their opinion, politicians will take these opinions into account.

- Elections cannot influence policies anymore.

- Influencing politicians makes no sense, since they cannot do something.

- MPś opinions do reflect what voters think.

- Politicians are ready to lie to us, when this can serve their own interests.

- If a politician acts in accordance with his/her values and his/her ideas, his/her political career has little chance of being successful.

- I believe that politicians really care about people's well-being.

- Virtually all politicians are ready to forget the promises they have made, if this allows them to get more power.

For each of these 14 statements, respondents gave an answer on a 5-point scale where 0meant "totally agree" and 4 meant "totally disagree". These scores were converted to so that all low scores meant "low external political efficacy" and all high scores meant "high external political efficacy". We then calculated the average score taking values ranging from 0 ("low external political efficacy") to 4 ("high external political efficacy"). 
Submit or recommend next manuscript to SCIRP and we will provide best service for you:

Accepting pre-submission inquiries through Email, Facebook, LinkedIn, Twitter, etc. A wide selection of journals (inclusive of 9 subjects, more than 200 journals)

Providing 24-hour high-quality service

User-friendly online submission system

Fair and swift peer-review system

Efficient typesetting and proofreading procedure

Display of the result of downloads and visits, as well as the number of cited articles

Maximum dissemination of your research work

Submit your manuscript at: http://papersubmission.scirp.org/ 